\title{
EPSL
}

Earth and Planetary Science Letters 121 (1994) 477-494

\section{Oblique convergence, indentation and rotation tectonics in the Taiwan Mountain Belt: Insights from experimental modelling}

\author{
Chia-Yu Lu ${ }^{\text {a }}$, Jacques Malavieille ${ }^{\mathrm{b}}$ \\ ${ }^{a}$ Geological Institute, National Taiwan University, Taipei, Taiwan, China \\ ${ }^{b}$ Laboratoire de Geologie Structurale, Université Montpellier II, Montpellier, France
}

(Received January 15, 1993; revision accepted December 6, 1993)

\begin{abstract}
Experimental modelling allows one to describe the development and kinematics of structures in mountain belts formed during oblique convergence. In the collision geometry of the Taiwan mountain belt, the Chinese continental margin is oriented about $\mathrm{N} 60^{\circ} \mathrm{E}$, whereas the $\mathrm{N} 16^{\circ} \mathrm{E}$ Philippine Sea plate backstop is moving toward the Eurasian plate in the $\mathrm{N} 55^{\circ} \mathrm{W}$ direction. Sandbox experiments have been conducted to simulate the Cenozoic arc-continent collision in Taiwan with a foreland-dipping backstop. The kinematics of deformation comprises a combination of compression and rotation which locally result in a partitioning between thrusting and wrenching. The experimental modelling shows that the faults or shear zones are rotated around the indentation point of the backstop by transcurrent and bookshelf faulting. An overall clockwise rotation (or right-lateral movements) occurs to the north of the indentation point and anticlockwise rotation occurs to the south of the indentation point. Oblique indentation and rotation structures can be demonstrated by (1) the crescent shape of the thrust wedge, (2) pull-apart structures induced by strike-slip tectonics, and (3) bookshelf-type strike-slip faulting resulting from the block rotation around the indentation point.
\end{abstract}

\section{Introduction}

Curved mountain belts are distributed widely throughout the world and can be subdivided into two groups: (1) gently curved mountain belts such as the Himalayas, Appalachian Mountains and Central European Alps, and (2) syntaxes in which structural directions change by $\approx 180^{\circ}$, such as the Western Alps and the eastern Himalayas syntaxes. Most of the these curved mountain belts are created by oblique convergence and the im-

[PT] pingement of arc or continental blocks or continental margins during the orogeny (i.e., indentation tectonics), which subsequently causes deformation and rotation of the foldbelt [e.g., 1-6]. During the oblique convergence and indentation deformation, thrust and strike-slip motion are the two major tectonic processes which lead to the development of deformation structures such as folds, foliations and mylonites in ductile to brittle-ductile shear zones, and thrust and strike-slip faults in the brittle field.

In the last decade, structural work on thrust belts [e.g., 4,7-11], experimental work [e.g., 12-18] and discussions of 3D kinematics of continental 
convergence and collision [6,10,19-21] have allowed the description of the geometry and mechanics of thrust wedges and collision tectonics. However, due to the scale factor and mechanical constraints on the application of analogue models to natural examples [22,23], the kinematics of oblique convergence, indentation in mountain belts and the partitioning of thrusts and strike-slip motion are still open questions.

The Taiwan Mountain Belt is an active curved thrust wedge and represents an ideal tectonic setting for examining the process of oblique convergence, indentation and rotation tectonics, because (1) the recent kinematics of nlate move-

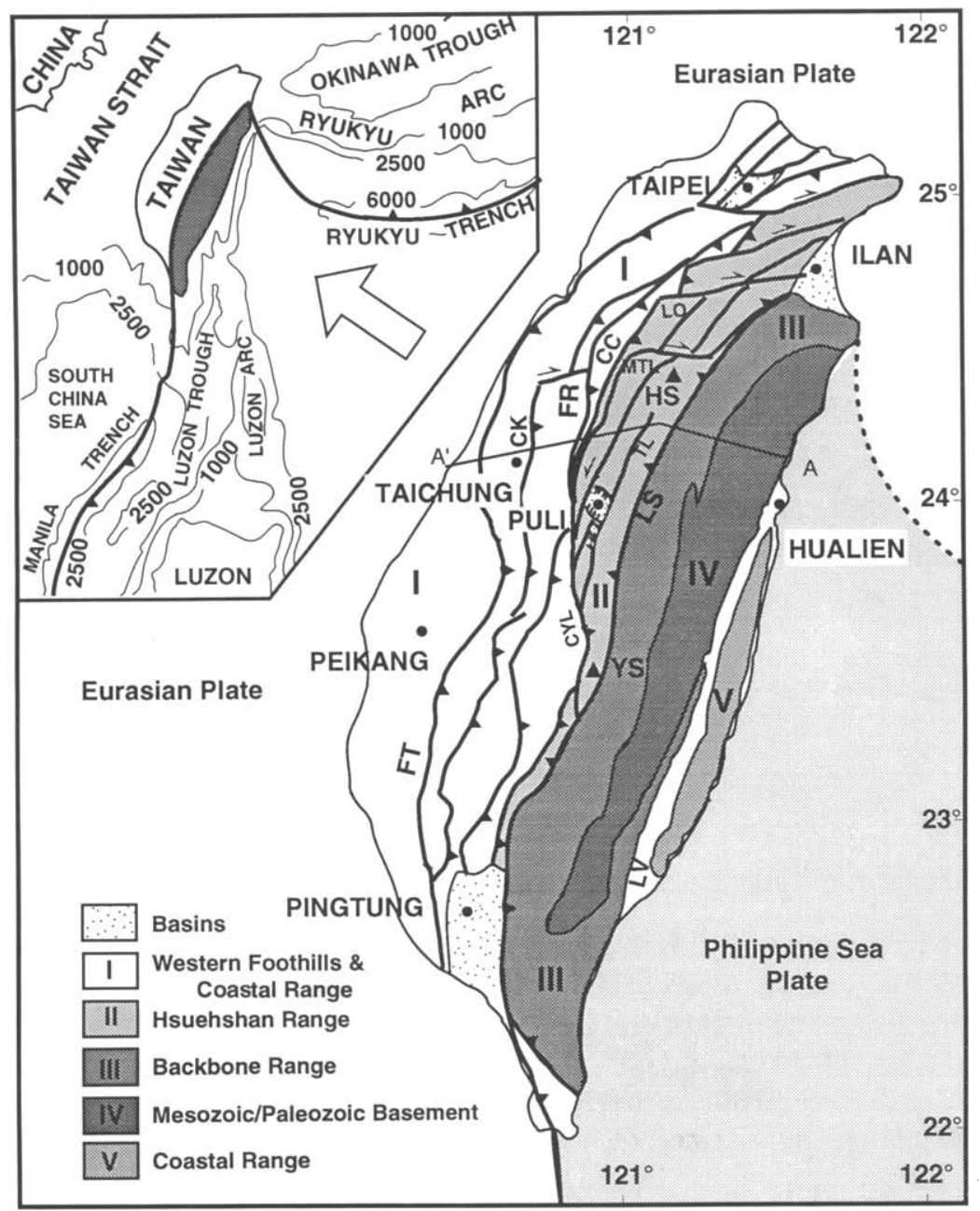

Fig. 1. Location map and main stratigraphic units of Taiwan. (compiled from $[59,66]$ ). General tectonic map (upper left): Isobaths in metres; large open arrow = direction of convergence (Philippine Sea plate relative to Eurasia). Main map: Heavy barbed lines with triangles on the upthrust side = major thrust faults. $C C=$ Chiuchih fault; $C K=$ Chukou fault; $C Y L=C h e n y u l a n c h i$ fault; $F R=$ Frontal Range thrust (Chishan-Chinkuashih line); $F T=$ Foothill thrust (Kaohsiung-Tanshui line); $L O=$ Loshan fault; $L S=$ plate boundary fault (Hengchun-Ilan line); $M T L=$ Matalanchi fault; $T L=$ Tili fault; $L V=$ Longitudinal Valley; $Y S=$ Yushan. 
ment around Taiwan are well known, (2) deformation is relatively simple because Taiwan is isolated from mainland China, and (iii) our geodynamic understanding of the Taiwan thrust wedge is well advanced.

This paper is an attempt to use 3D sandbox modelling to better understand the kinematics of the Taiwan thrust wedge and to interpret the structures produced by the oblique convergence, indentation and rotation tectonics.

\section{Previous work}

A significant feature of the Taiwan Mountain Belt is its abrupt change in trend from Northern Taiwan to Central Taiwan (between 24 and $25^{\circ} \mathrm{N}$ ), with the angle of difference ranging from $40^{\circ}$ in the Western Foothills to about $90^{\circ}$ at the eastern boundary of the Backbone Range (Fig. 1). Much work has been done on this subject: Tan [24] first pointed out the bending of the Taiwan arc and interpreted it as a result of subduction. Suppe [25] interpreted the bending as the result of flipping of subduction direction and the opening of the Okinawa Trough. Lue et al. [26] and Lee et al. [27] used geomagnetic data to show that Northern Taiwan has undergone an average rotation of approximately $20^{\circ}$. Based on paleostress analysis, Angelier et al. [28] interpreted the curvature (about $20^{\circ}$ ) as being partially the result of block rotation during the Plio-Pleistocene and partially an initial change in the structural trend without block rotation.

The deformation and metamorphism of the Taiwan thrust wedge have been well studied, and various models are presently advocated $[11,13$, 29-31]. However all these models are constrained by frontal convergence. Finite element methods have been conducted in order to reconstruct the paleostress fields [32,33] and to account for the observed transcurrent movement $[19,34,35]$. However, these methods are limited to two dimensions and cannot easily take into account long and narrow shear zones with large displacements.

To better describe and understand the complex structures that may result from oblique collision and indentation of the thrust wedge, we used the same experimental modelling approach as Davis et al. [13], with emphasis on the important boundary conditions in Taiwan mountain building, i.e. oblique convergence and indentation. $\mathrm{Pa}$ rameters such as basal friction, model thickness, and backstop dip have already been studied in 2D experiments by Mulugeta [16], Lui et al. [18] and Malavieille et al. [36]. In this study, we use a large-scale sandbox which allows significant shortening and 3D analysis of structures after deformation.

\section{Geological setting}

Taiwan is located on the boundary between the Eurasian plate and the Philippine Sea plate and, more specifically, on the junction between of the Luzon arc and the Ryukyu arc (Fig. 1). The lithosphere of the Eurasian plate around Taiwan includes the crust of the Chinese continental margin and the oceanic crust of the South China Sea. The Philippine Sea plate is subducting beneath the continental part of the Eurasian plate at the Ryukyu Trench, and overrides the crust of the South China Sea at the Manila Trench.

Taiwan can be divided into five major tectonostratigraphic units, including, from the west to the east, the Coastal Plain and Western Foothills, the Hsuehshan Range, the Backbone Range Slate Belt, the Paleozoic-Mesozoic basement, and the Coastal Range (Figs. 1 and 2).

The Coastal Plain and Western Foothills are composed of Oligocene-Miocene-Quaternary sedimentary rocks. The stratigraphy is naturally divided into two sequences by a regional lower Oligocene unconformity [37]. The units near the unconformity function as the basal decollement in the Western Foothills fold and thrust belt [38].

The Hsuehshan Range is composed of quartzites and slates of Eocene-Oligocene age representing a passive margin shallow-marine sequence. This sequence is characterized by transgressive and rift facies [39-41].

The Backbone Range Slate Belt is a huge mass of dark grey flysch and phyllite intercalated with limestone blocks and igneous rocks such as pillow lavas, diorite, gabbro, minor andesite, dolerite, 
and pyroclastic products. This unit is distinguished by a lack of stratal continuity and an intense layer-parallel shearing with bedding cleavage. All the characteristics of a tectonic mélange, or broken formation, are common.

The Paleozoic-Mesozoic basement is composed of three lithological units. The first has been interpreted as a Mesozoic mélange complex in an ancient accretionary wedge or suture zone $[42,43]$. The second consists exclusively of massive marbles. Radiometric dating suggests a Paleozoic age [44]. The third unit consists of Cretaceous granitoids.

The Coastal Range is composed of deformed rocks of the Miocene volcanic arc and forearc basin of the Luzon arc, together with an overlying Pliocene and Pleistocene molasse sequence of about $4-5 \mathrm{~km}$ in thickness and the Lichi Mélange [45].

\section{Boundary conditions of the collision}

\subsection{Westward dip of the backstop}

The backstop is the boundary where sediments accreted are above either the crystalline leading edge of the overriding plate [46] or the more highly consolidated remnants of previous episodes of accretion [47].

$\mathrm{Lu}$ and Hsü [48] proposed that the PaleozoicMesozoic basement was rifted and drifted away from the southeastern coast of mainland China and became part of the Philippine Sea plate after the late Cretaceous. The Backbone Range Slate Belt and the Kenting Mélange are interpreted as a part of the Miocene accretionary wedge. The boundary between the Backbone Range and the Hsuehshan Range is considered to be the boundary between the Philippine Sea plate and the

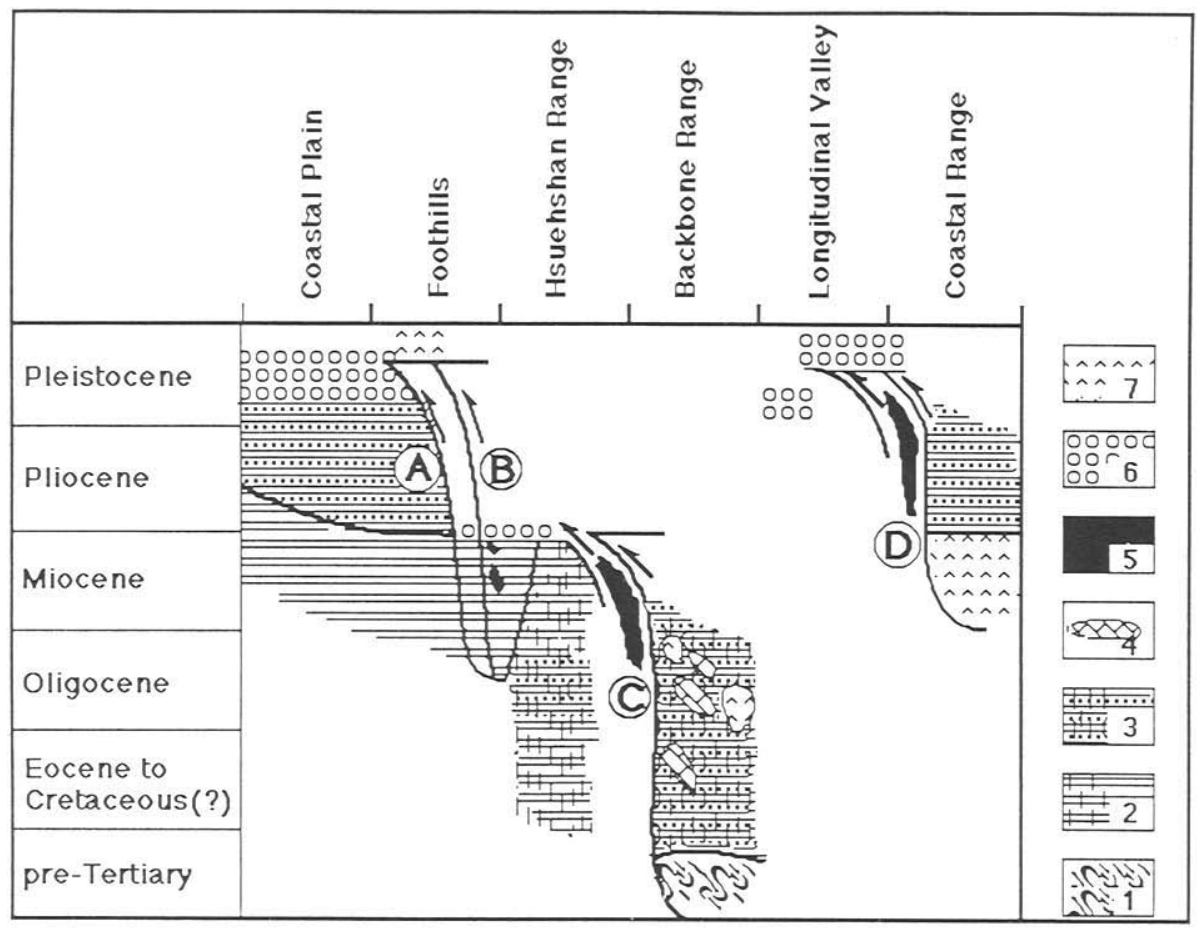

Fig. 2. The distribution in time and space of the rock groups in Taiwan (modified after $[61,62]$ ). $1=$ Paleozoic-Mesozoic basement; $2=$ shelf sediments, partly converted into low-grade metamorphics (hatched); $3=$ flysch and flyshoid sediments; $4=$ marble; $5=$ ophiolitic mélange; $6=$ molasse; $7=$ arc andesite. 


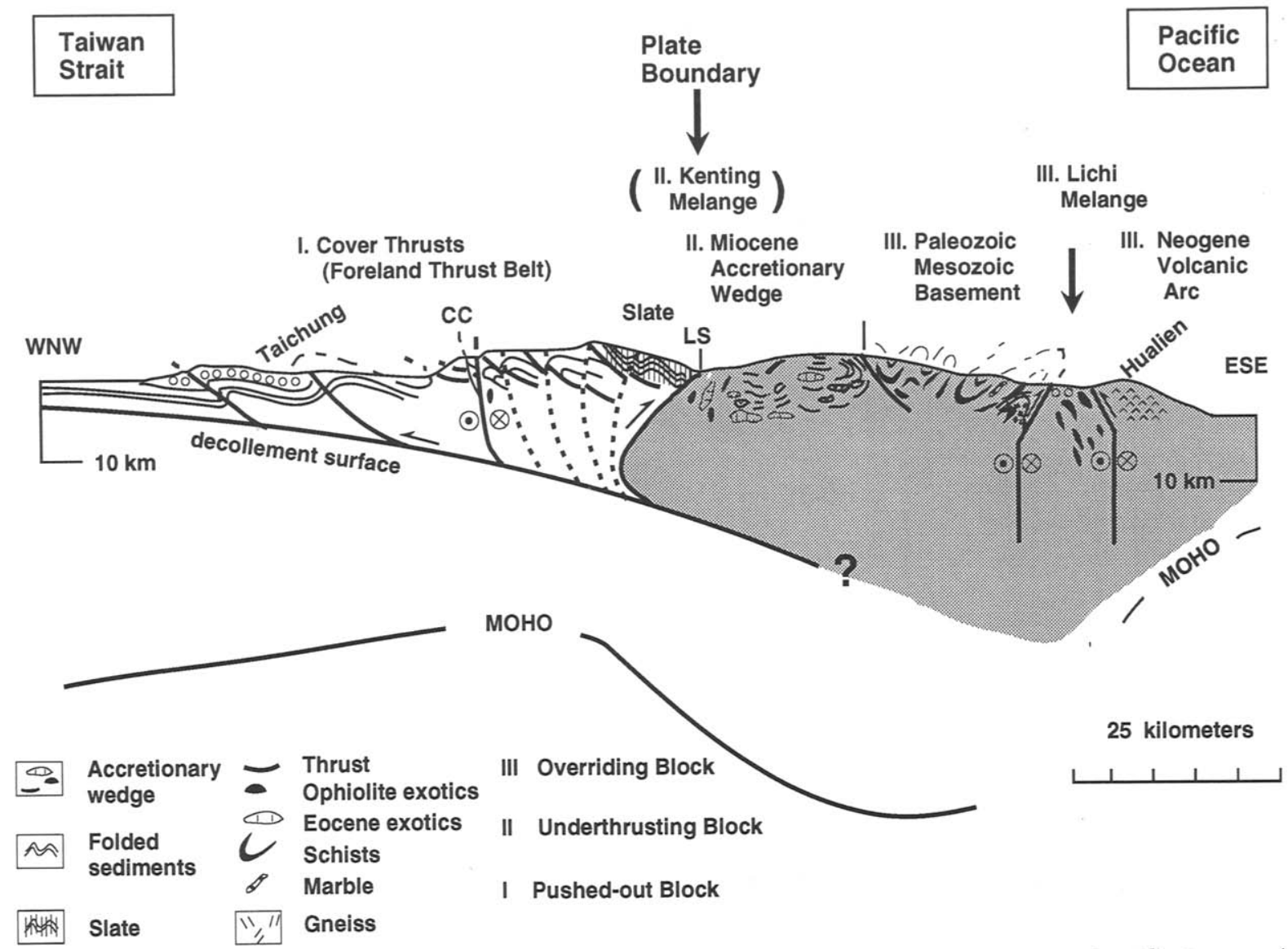

Fig. 3. General structural section of Central Taiwan. Location is shown in Fig. 1 (line $A-A^{\prime}$ ) (modified after [48,59]). Grey part is regarded as the backstop of the models in this paper.

Eurasian plate. The Lichi Mélange is inferred to be a Plio-Pleistocene intraplate subduction mélange (Fig. 6 in [48]). According to these interpre- tations, there were two collision events during the Cenozoic Taiwan orogeny. The western boundary of the Paleozoic-Mesozoic basement is regarded

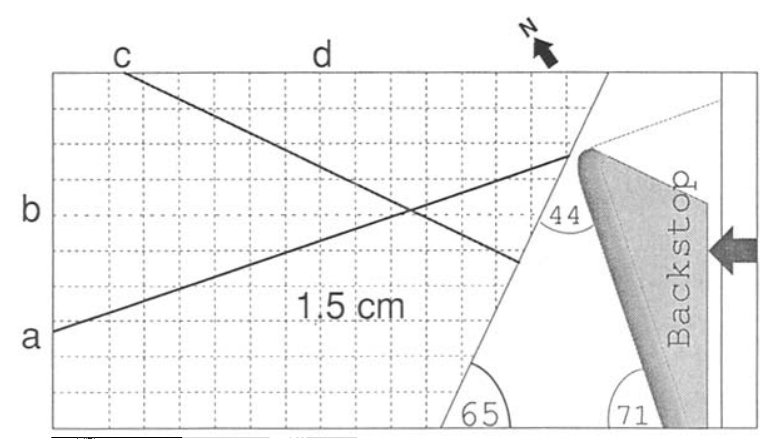

Fig. 4. Experimental boundary conditions of oblique convergence and collision model: Backstop dip $=30^{\circ}$, low basal friction, free borders, length $=200 \mathrm{~cm}$, width $=100 \mathrm{~cm}$, thickness of sandcake $=1.5 \mathrm{~cm}$. 


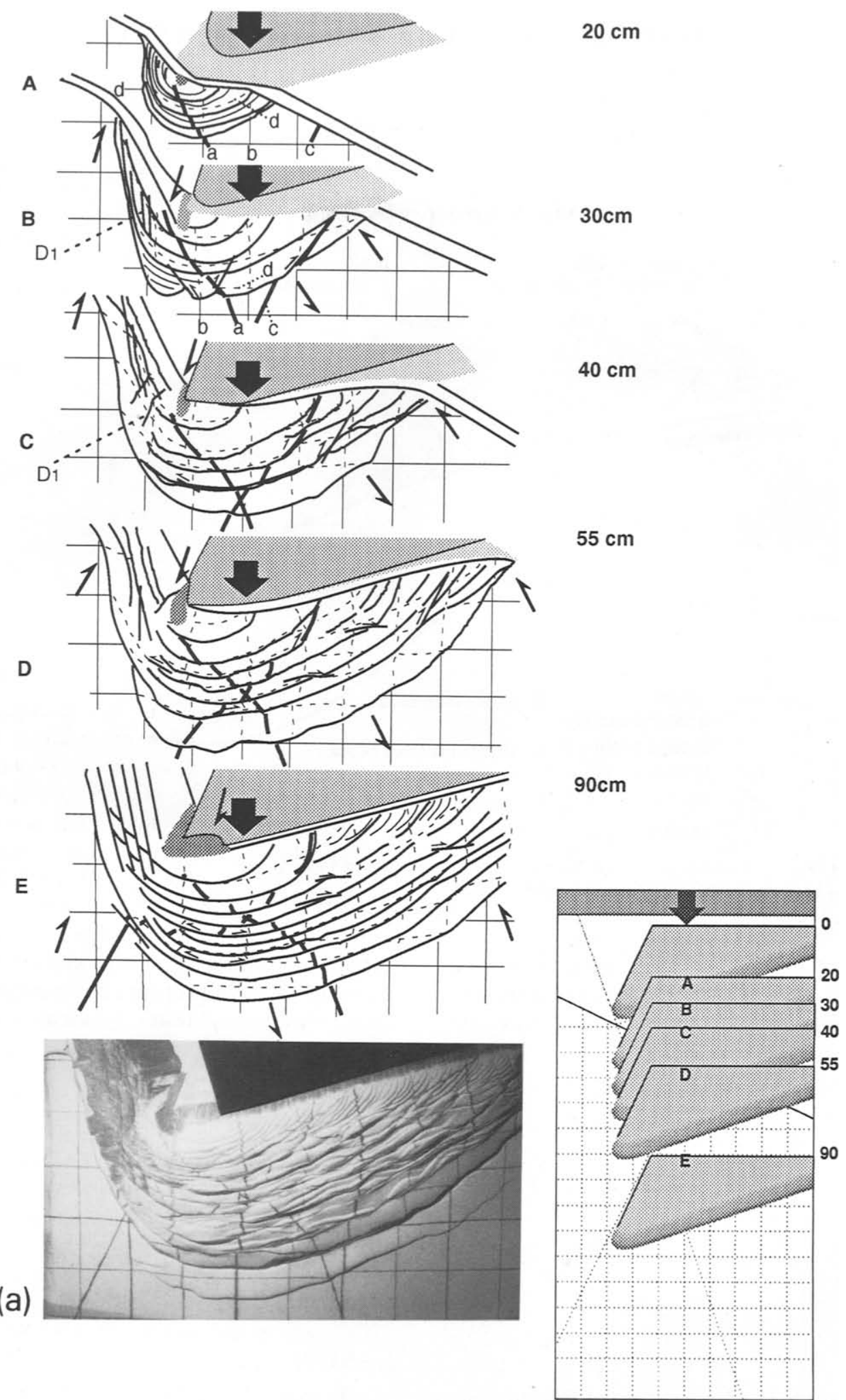

Fig. 5 (a). Experimental evolution of sandbox model. (b) Detail of Fig. 5a, E. 


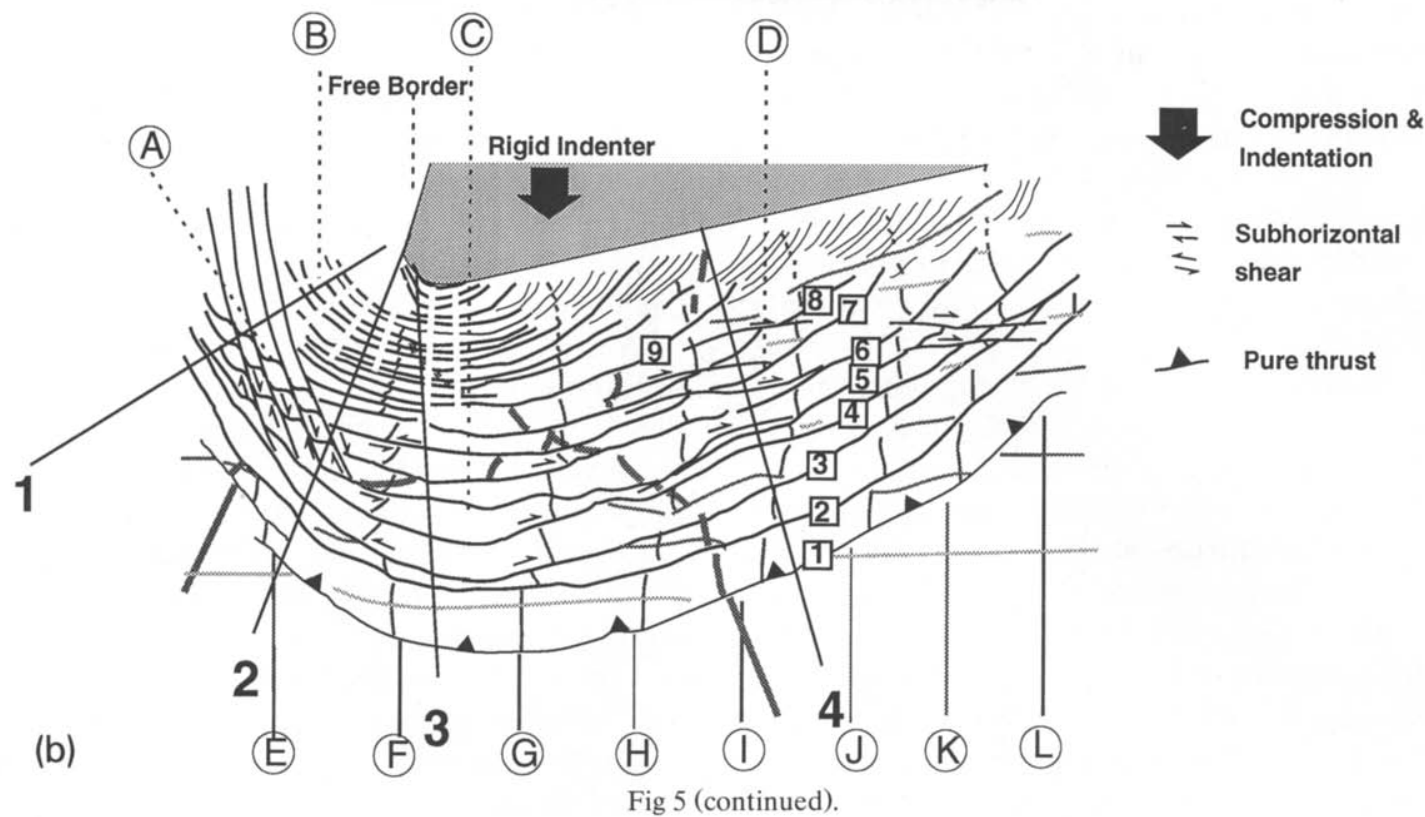

as the crystalline leading edge of the overriding plate and the Backbone Range Slate Belt is inferred to represent the remnants of previous episodes of accretion.

The general lithological distribution and structure of Central Taiwan is shown in Fig. 3. The contact between the Paleozoic-Mesozoic basement and the Backbone Range is marked by a mylonitic fault zone associated with a kilometrescale overturned synform structure in the Backbone Range Belt. The boundary between the Hsuehshan Range and the Backbone Range on the Central Cross Island Highway is presently mapped as a major west-dipping back thrust (the Lishan fault), based on updip stretching lineations and a reverse movement sense indicated by asymmetric pressure shadows in the slate units [49]. This fault separates the active part of the Taiwan Mountain Belt from the older metamorphic domain that acquired its structure before the second collision.

Our study is mainly concerned with the postcollision deformations to the west of Lishan fault, in the foreland thrust belt. The old metamorphic tectonic units situated east of this boundary fault may be regarded as a relatively rigid backstop during the active foreland wedge building. From this line reasoning we build foreland (westward) dipping rigid backstops in our experiments.

In the same way, the geometrical boundary conditions of the models have been designed according the present collision geometry of the Taiwan Mountain Belt (Fig. 4). The Chinese continental margin is oriented about $N 60^{\circ} \mathrm{E}$, the Backbone Range Slate Belt $\mathrm{N} 16^{\circ} \mathrm{E}$, and the trend of the Ryukyu Trench along the eastern boundary of Northern Taiwan is estimated at $\mathrm{N} 29^{\circ} \mathrm{W}$, based on the bathymetric map. The Philippine Sea plate is moving towards the Eurasian plate in the $\mathrm{N} 55^{\circ} \mathrm{W}$ direction [50,51].

\section{Experimental set-up and procedure}

The principle of our apparatus is similar to that used by Davis et al. [13], but our device is large enough to model the Taiwan boundary conditions and oblique collision. In our study we used dry cohesionless quartz sand with a NavierCoulomb rheology and an angle of friction of about $30^{\circ}$; these characteristics are similar to those of many sedimentary rocks. The density of 
the sand is about $1.6 \mathrm{~g} / \mathrm{cm}^{3}$, and the homogeneous grain size (less than $300 \mu \mathrm{m}$ ) was obtained by sieving. The liquid colouring used to pick out the sand layers did not significantly modify the non-cohesive nature of the sand grains after drying. Sand constitutes a good analogue for modelling brittle Mohr-Coulomb behaviour during the surficial deformation of sedimentary material $[23,52,53,54]$.

The models were built by laying horizontal layers of coloured sand onto a PVC plate. A rigid mobile backstop pushes (at slow speed $-5 \mathrm{~cm}$ / min) the sand over the basement plate, generating a Coulomb thrust wedge. The amount of shortening is large enough to reach the critical taper of the wedge after $50 \mathrm{~cm}$. The width of 100 $\mathrm{cm}$ allows us to study the influence of lateral variations in the model far from the localized boundary effects. A passive grid of coloured lines was lain on the models, allowing observation of the kinematics of the surface deformation. The experiments were video-recorded and photographed vertically at shortening intervals of about $5 \mathrm{~cm}$. After complete deformation, the models were impregnated with water and sectioned in different directions (perpendicular, parallel and oblique to the backstop) in order to reconstruct the 3D geometry of the internal structures.

\section{Experimental results}

We do not attempt to provide an exhaustive description of the experiment for each step of the deformation, but instead we focus on describing the main stages necessary to the understand genesis and evolution of the thrust wedge. We define the shortening for each step studied as a function of the collisional indentation distance.

Four sets of line markers were used to show the kinematics of faulting (Fig. 4), the first perpendicular to the backstop (a lines), the second parallel to the compression direction (b lines), the third perpendicular to the left-hand margin of the model (c lines), and the fourth perpendicular to the movement direction (d lines).
The parameters of the described model are as follows: backstop dip $=30^{\circ}$, low basal friction, $\phi_{\text {basal }} \approx 18^{\circ}$, and laterally free borders (Fig. 4).

The experimental results are as follows:

\subsection{Vertical view of the experiment}

\section{Qualitative descriptions}

A curved thrust wedge was built up at the beginning of the collision. At $20 \mathrm{~cm}$ of shortening the wedge was constructed by $\sim 1 \mathrm{~cm}$ spaced imbricate thrusts (Fig. 5a, $A$ ). The surface structures were also curved. At this stage, the displacement of the a lines indicates a left-lateral strike-slip movement (or block rotation) superimposed on the thrusts to the right of the indentation point. The orientation of $\mathbf{b}$ lines in the wedge was virtually undisturbed, whereas the d lines within the wedge were curved and associated with curved thrust faults. The frontal thrust unit remained continuous.

At $30 \mathrm{~cm}$ shortening (Fig. $5 \mathrm{a}, B$ ), a $\sim 5 \mathrm{~cm}$ spaced (surface offset) frontal thrust jumped out. The $\mathbf{d}$ line above the frontal thrust was straight, $\mathbf{b}$ lines within the wedge were slightly stretched parallel to the surface trace of thrusts, a remarkable apparent right-hand displacement of $\mathbf{c}$ lines appeared between the wedge and the undeformed sandcake, and gravity sliding occurred at the free border (grey area). With continued shortening a new set of dextral strike-slip faults (D1) (cf. Fig. 5a), parallel to the slip line [55], developed to the left of the indentation point and cut previous clockwise curved thrusts. A left-lateral strike-slip fault developed in the 10 o'clock direction relative to the $\mathbf{b}$ line, and the wedge shape became more asymmetrical.

At $40 \mathrm{~cm}$ shortening (Fig. $5 \mathrm{a}, C$ ), the a, c and d lines retained the same characteristics as in the previous stages. The thrusts turned around the indentation point, and three different domains were distinguished:

(1) To the right of the indenter, oblique thrusts showed a left-lateral component of slip, the internal part of the wedge (near the backstop) accommodated left-lateral simple shear deformation by right-lateral bookshelf strike-slip faulting [56]. 
Table 1

The rotation angles of marker segments which parallel the convergence direction. The numbers $1-9$ on the left indicate the large discontinuities in Fig. 5b

\begin{tabular}{|c|c|c|c|c|c|c|c|}
\hline & \multicolumn{7}{|c|}{ Rotation angle } \\
\hline & $\bar{E}$ & $\mathbf{F}$ & $\mathbf{G}$ & $\mathbf{H}$ & I & $\mathbf{J}$ & $\bar{K}$ \\
\hline$\sim 1$ & 0 & 0 & 0 & 0 & 0 & 0 & 0 \\
\hline $1 \sim 2$ & .7 & 4 & -2 & -3 & -3 & -2 & 6 \\
\hline $2 \sim 3$ & -6 & 5 & 24 & -3 & -2 & 5 & 4 \\
\hline $3 \sim 4$ & & -49 & 22 & 2 & -3 & 4 & 12 \\
\hline $4 \sim 5$ & & -49 & 8 & 3 & 8 & 5 & 20 \\
\hline $5 \sim 6$ & & -36 & 8 & & 18 & 18 & \\
\hline $6 \sim 7$ & & -47 & 48 & & & & \\
\hline $7 \sim 8$ & & -22 & 10 & & & & \\
\hline $8 \sim 9$ & & -14 & 26 & & & & \\
\hline
\end{tabular}

(2) To the left of the indenter a right-lateral shear zone developed, the internal part of the wedge underwent right-lateral simple shear deformation and left-lateral bookshelf strikeslip faulting occurred.

(3) In front of the indenter significant stretching occurred perpendicular to the convergence direction, as indicated by the $\mathbf{b}$ lines in the wedge. The D1 structures were well developed, but the spacing of frontal thrusts still remained $\sim 5 \mathrm{~cm}$.

From $55 \mathrm{~cm}$ (Fig. $5 \mathrm{a}, D$ ) to $90 \mathrm{~cm}$ (Fig. $5 \mathrm{a}, E$ ) shortening, the same kinematics as those previously described continued. However, the rightlateral bookshelf strike-slip faulting migrated to the right as the free border at the right-hand side shifted to the right due to the approach of the asymmetrical indenter. The $\mathbf{c}$ lines showed opposite displacement on either side of the indenter. Figure $5 \mathrm{~b}$ represents a detailed vertical view of the most evolved stage of the experiment $(90 \mathrm{~cm}$ shortening).

\section{Quantitative analysis}

Table 1 lists the rotation angles for each segment that was cut by the thrusts of the markers parallel to the convergence direction in Fig. 5b, the negative angles representing clockwise rotation and the positive anticlockwise rotation. The numbers in the left-hand column represent the segment between the thrust units (cf. Fig. 5b). Columns (i.e., lines) $F$ and $G$ show the larger rotation angles around the indenter. The large

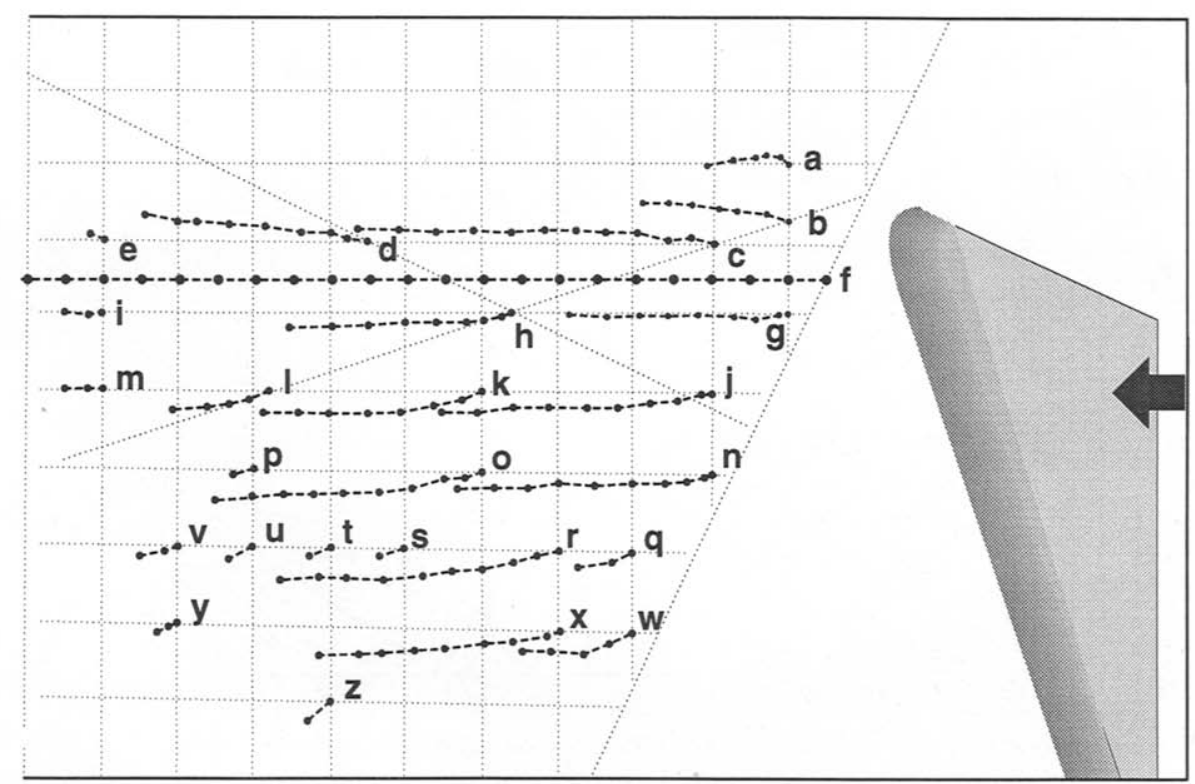

Fig. 6. Displacement trace of the intersection points of markers during the progressive deformation. 
rotation angles that occurred in the 4-5 and 5-6 segments on lines $I, J$ and $K$ are associated with a high density of right-lateral bookshelf-type strike-slip faulting in those areas (see also Fig. 7, section 4). Table $2 \mathrm{~A}$ lists the orientation differences $(\beta)$ for different fault segments (numbered as $1,2,3$, etc. in the left-hand column) in relation to a direction perpendicular to the convergence direction in Fig. 5b. Table $2 \mathrm{~B}$ shows the instantaneous partition of the strike-slip component $(=$ $\sin \beta$ ) during wedge formation. We know that the internal friction coefficient $(\mu)$ of our sand model
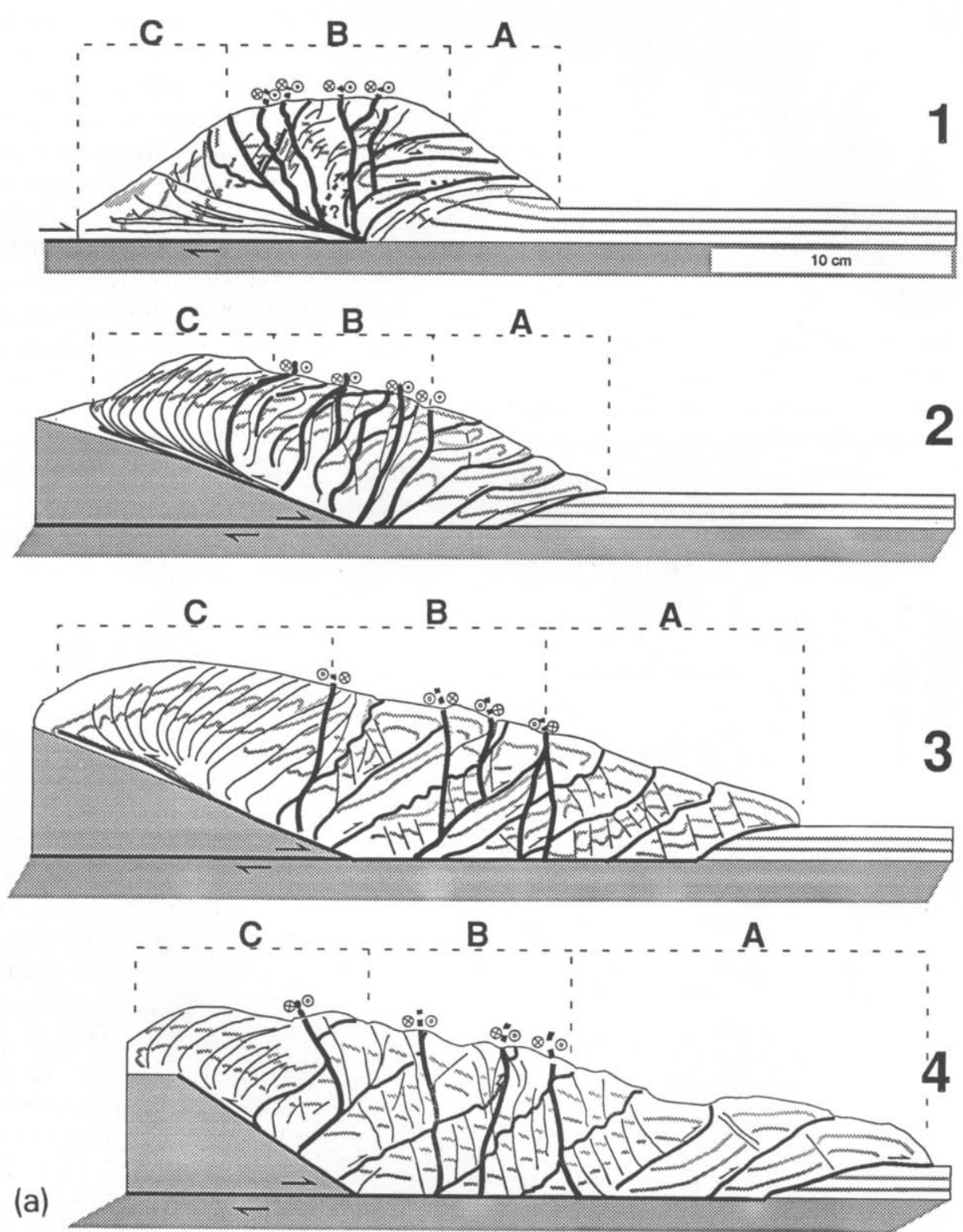

Fig. . V vèrtical cross sections perpenaicular to tne tnrust tronts snowing tne aeep-seatea geometry oI tnrusts in tne oblique collision zone (see also the four accompanying photographs). The different apparent dip of the backstop is due to the oblique views of the photographs, which were taken perpendicular to the direction of convergence. 

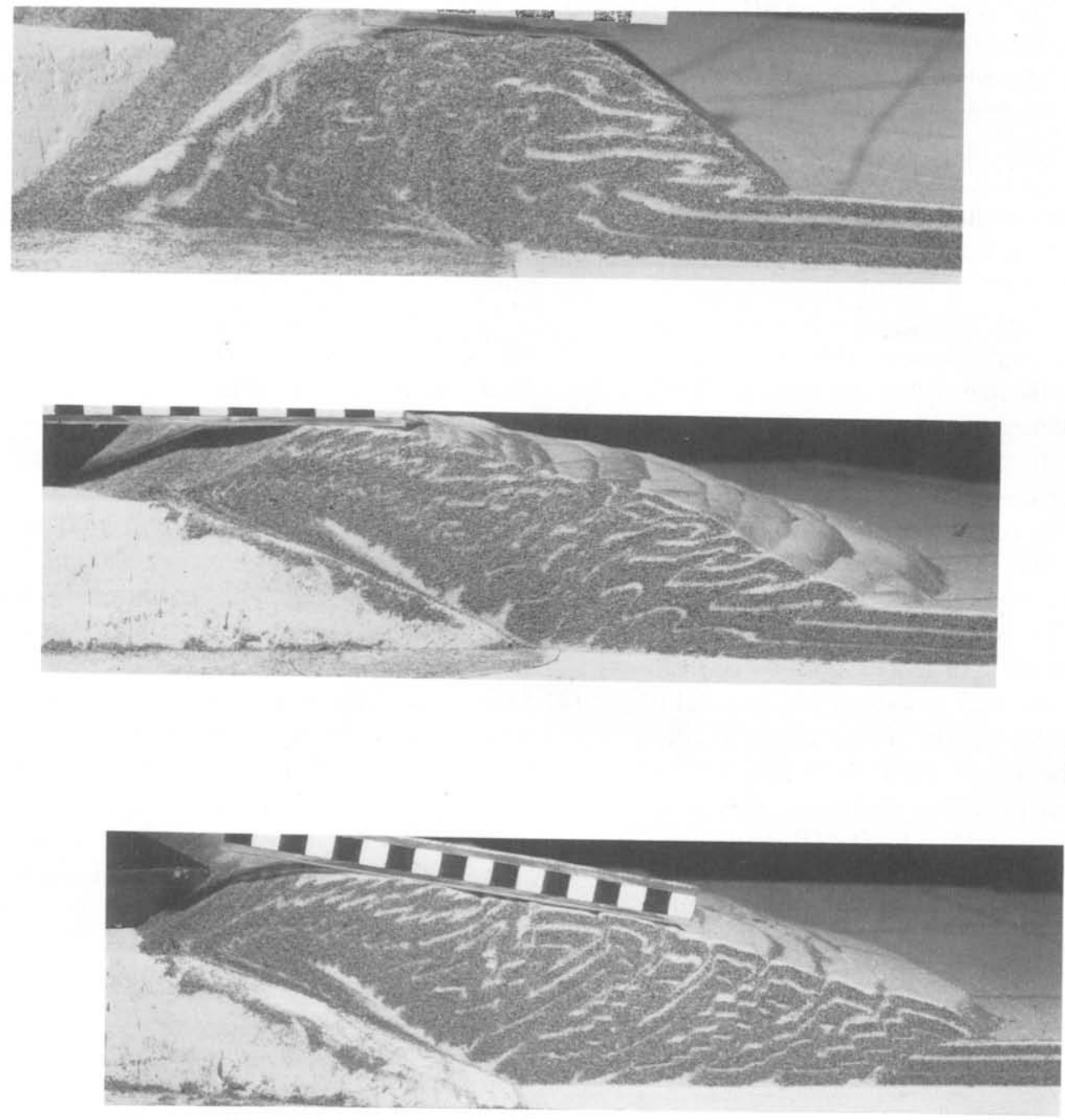

(b)

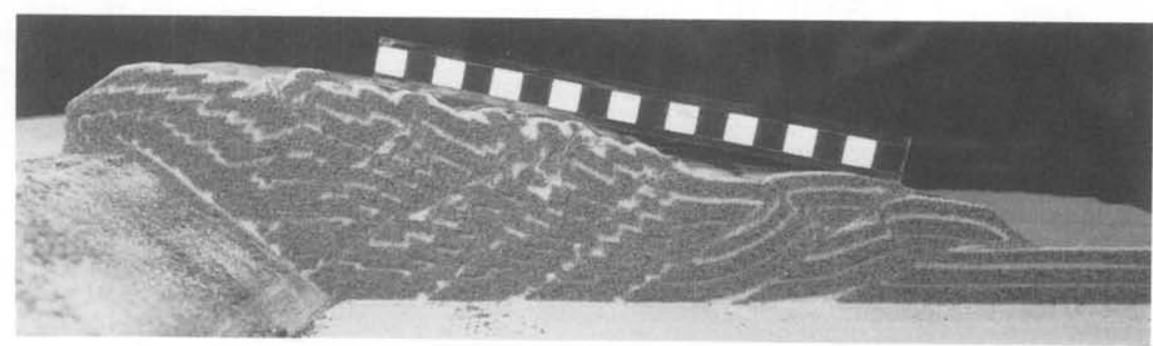

Fig. 7 (continued). 
is about 0.58 and we can therefore assume that the average thrust dip is $30^{\circ}$, following the equation of Fitch [19] (i.e., $\cos \beta>(3 \mu \sin \beta) / 2)$. In this case, angles of oblique slip as large as $49^{\circ}$ satisfy the inequality, which implies that most of the discontinuity, except for some segments to the left of the $E$ line, tend to be oblique thrusts.

Fig. 6 shows the movement paths of markers of the intersection points during the progressive deformation. Table 3 gives the measured orientation of the displacement vector relative to the convergence direction, the negative angles representing clockwise displacement and the positive anticlockwise displacement. For each intersection point, the displacement vector of the first step is perpendicular to the border of the backstop. During the following steps the vectors tend to parallel the convergence direction and after two or three steps (about a $15 \mathrm{~cm}$ advance of the backstop) the displacement vectors are parallel to the convergence direction. The $\mathbf{f}$ line is an idealized line of the indentation trace. All traces tend to diverge from the $f$ line at the first few steps and parallel it at later stages, although the a line tends to converge towards the $f$ line after the second step, with the displacement subparallel to the strike-slip faults (Fig. 5b). The ratio $D^{\prime} / D\left(D^{\prime}\right.$ represents the measured horizontal displacement of the intersection point and $D$ is the displacement of the backstop-about $5 \mathrm{~cm}$ in each step) indicates that the vertical displacement is concentrated in most of the first few steps of the displacement traces.

The overall deformation features resulting from indentation of the oblique margin are summarized below:

(1) Crescent shape of the thrust wedge.

(2) Deformation within the right-hand part of the thrust wedge model results in left-lateral oblique thrust motion (including left-lateral block rotation and simple shear in the internal zone) and right-lateral bookshelf strikeslip faulting as shown by surface markers $G$, $H, I, J$ and $K$ (Fig. 5b).

(3) In front of the rigid backstop (indenter) the thrust units were continuously deformed and internal deformation was characterized by transpression indentation uplift and thrustparallel stretching. This effect enhanced the rotation of the segments bounded by the $F$ and $G$ lines. Fanning extensional stretching developed in areas $B$ and $C$ (Fig. 5b).

(4) Due to the free border situated on the lefthand side of the indenter and large displacement of the backstop, right-lateral transcurrent faults developed and subsequently highangle strike-slip faults cut and displaced the thrust wedge. This resulted in a sigmoidal shape fabric of some of the tectonic units (area $A$ in Fig. 5b).

Table 2

The obliquity of each segment of the discontinuities in Fig. 5b and instant partition of the strike-slip component

A

B

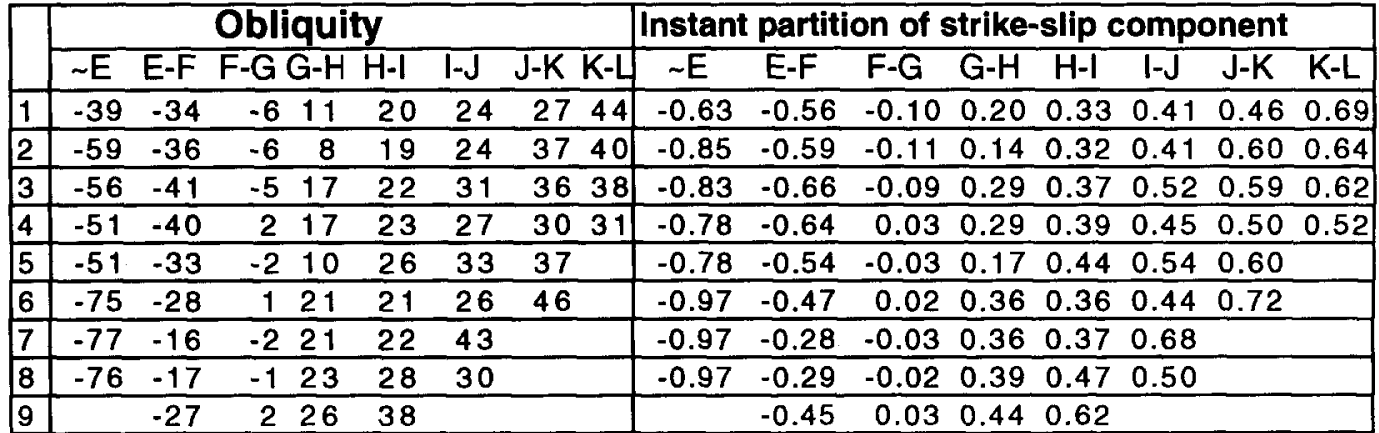


(5) The offset of surface markers depends on their initial orientation and location relative to the indenter (Fig. 5b, Fig. 6 and Table 1).

(6) The frontal thrusts were first developed as pure thrusts (Fig. 6). As the wedge advanced these thrusts were progressively accommodated by oblique movement and became oblique-slip thrusts or strike-slip faults.

\subsection{Details of the cross sections}

A set of cross sections perpendicular to the wedge shows the deep-seated relationships between the different structures. All the sections are characterized by three different domains (A, $\mathbf{B}$ and $\mathbf{C}$ ) relative to the backstop (Fig. 7).

Section 1 is situated to the left of the indenta-

Table 3

The displacement traces of the intersection points of markers during the experiment

\begin{tabular}{|c|r|r|r|r|r|r|r|r|r|r|r|}
\hline trace & \multicolumn{1}{|c|}{$\alpha$} & $\mathrm{D}^{\prime} / \mathrm{D}$ & trace & $\alpha$ & $\mathrm{D}^{\prime} / \mathrm{D}$ & trace & $\alpha$ & $\mathrm{D}^{\prime} / \mathrm{D}$ & trace & $\alpha$ & $\mathrm{D}^{\prime} / \mathrm{D}$ \\
\hline $\mathbf{a}$ & -41 & $\geq 0.28$ & $\mathbf{e}$ & -22 & $\geq 0.40$ & $\mathbf{k}$ & 23 & $\geq 0.57$ & $\mathbf{p}$ & 5 & $\geq 0.57$ \\
& -8 & 0.38 & $\mathbf{g}$ & 6 & $\geq 0.24$ & & 11 & 0.76 & $\mathbf{q}$ & 25 & $\geq 0.58$ \\
& 13 & 0.28 & & 12 & 0.61 & & 11 & 0.89 & & 8 & 0.91 \\
\hline & 6 & 0.58 & & -8 & 0.57 & & 2 & 0.88 & $\mathbf{r}$ & 12 & $\geq 0.59$ \\
& 12 & 0.70 & & -2 & 0.94 & & 0 & 0.99 & & 16 & 0.65 \\
$\mathbf{b}$ & -18 & $\geq 0.60$ & & 2 & 0.80 & & 1 & 0.80 & & 12 & 0.84 \\
& -6 & 0.77 & & 0 & 0.80 & & 0 & 0.93 & & 4 & 0.80 \\
& -7 & 0.48 & & 2 & 0.85 & $\mathbf{I}$ & 13 & $\geq 0.57$ & & 9 & 0.79 \\
& -8 & 0.71 & & -3 & 0.94 & & 13 & 0.54 & & -2 & 0.98 \\
& -5 & 0.63 & $\mathbf{h}$ & 22 & $\geq 0.27$ & & 7 & 0.58 & & -3 & 0.96 \\
& 0 & 0.70 & & 12 & 0.49 & & 5 & 0.90 & & 4 & 0.99 \\
\hline $\mathbf{C}$ & -15 & $\geq 0.62$ & & 6 & 0.45 & $\mathbf{m}$ & 0 & $\geq 0.40$ & $\mathbf{s}$ & 5 & $\geq 0.86$ \\
& 7 & 0.62 & & 0 & 0.80 & & 0 & 0.60 & $\mathbf{t}$ & 12 & $\geq 0.62$ \\
& -14 & 0.85 & & 0 & 0.83 & $\mathbf{n}$ & 21 & $\geq 0.21$ & $\mathbf{u}$ & 27 & $\geq 0.70$ \\
& -1 & 0.83 & & 4 & 0.98 & & 14 & 0.47 & $\mathbf{v}$ & 20 & $\geq 0.37$ \\
& -4 & 0.78 & & 2 & 0.95 & & 5 & 0.58 & & 11 & 0.66 \\
& -1 & 0.83 & & 2 & 0.97 & & 0 & 0.86 & $\mathbf{w}$ & 27 & $\geq 0.84$ \\
& 3 & 0.91 & $\mathbf{i}$ & 8 & $\geq 0.35$ & & -4 & 0.95 & & 22 & 0.73 \\
& -2 & 0.98 & & -7 & 0.63 & & 8 & 0.93 & & -5 & 0.88 \\
& 2 & 0.98 & $\mathbf{j}$ & 3 & $\geq 0.28$ & & -1 & 0.89 & & 0 & 0.75 \\
& -4 & 0.99 & & 16 & 0.65 & & -1 & 0.98 & $\mathbf{x}$ & 20 & $\geq 0.37$ \\
& -3 & 0.98 & & 5 & 0.73 & $\mathbf{0}$ & 18 & $\geq 0.47$ & & 9 & 0.91 \\
$\mathbf{d}$ & -8 & $\geq 0.53$ & & 7 & 0.87 & & 3 & 0.55 & & 4 & 0.75 \\
& -19 & 0.45 & & 0 & 0.80 & & 17 & 0.89 & & 10 & 0.79 \\
& -1 & 0.78 & & -1 & 0.99 & & 7 & 0.78 & & 4 & 0.80 \\
& -10 & 0.98 & & 0 & 0.94 & & 1 & 0.92 & & 4 & 0.90 \\
& -4 & 0.95 & & 8 & 0.96 & & 2 & 0.78 & & 3 & 0.96 \\
& -3 & 0.90 & & -1 & 0.94 & & 0 & 0.80 & & 1 & 0.99 \\
& -3 & 0.82 & & & & & 6 & 0.80 & $\mathbf{y}$ & 24 & $\geq 0.25$ \\
& -10 & 0.87 & & & & & 5 & 0.83 & & 27 & 0.34 \\
\hline & & & & & & & 4 & 0.98 & $\mathbf{z}$ & 40 & $\geq 0.78$ \\
\hline
\end{tabular}


tion trajectory. The A domain is dominated by foreland-vergent imbricate thrusts. The $\mathbf{C}$ domain is dominated by backthrusts and surficial gravitational sliding (in grey). The $\mathbf{B}$ domain is characterized by right-lateral strike-slip faults which cut or are superimposed on the previous imbricate thrusts, resulting in positive flower structures $[57,58]$.

Section 2 cuts the northern edge of the backstop. The A domain is characterized by low-dip ( $\sim 10^{\circ}$ in the upper part) imbricate ramps. Within the $\mathbf{C}$ domain, the main backthrust coincides with the slope surface of the backstop. Early-formed structures were largely displaced along the main backthrust towards the backstop. Numerous strike-slip faults, most of them left-lateral, were present in the B part of the model. The previously formed thrusts in this domain were cut into segments.

In section 3, the A domain shows small backthrust structures resulting from conjugate slipline-type thrusts that are penetratively developed in the imbricate thrust units. Pop-up structures were developed near the surface, and the early ramps were deformed into a staircase geometry. The $\mathbf{C}$ domain shows the same (backthrusting) structure as in section 2 . In the $\mathbf{B}$ domain the right-lateral strike-slip faults developed during progressive shortening induced by oblique convergence. They generally rework earlier small backthrusts (see also section 2) and cut previous staircase and pop-up structures.

The A domain of section 4 shows a well-developed pop-up structure. Some of the right-lateral strike-slip faults in the $\mathbf{C}$ domain were deformed during progressive shortening by the backthrusting mechanism. The slip-line-type backthrusts are concentrated in the $\mathbf{B}$ part.

\section{Discussion and conclusion}

Interpretation of natural tectonic situations with the help of model experiments must be done with caution. Sandbox experiments focus mainly on brittle to brittle-ductile structures in the accretionary wedge, to the exclusion of equally important ductile deformation. The influence of anisotropic layering on the deformation of sediments is not accounted for either. However, if one merely looks at the geometrical and kinematic aspects of the Coulomb wedges, analogies between Fig. 1 and Fig. 5b, and between section 3 of Fig. 7 and Fig. 3, certainly warrant attention.

Due to its geodynamic situation the Taiwan active mountain belt presents us with a special shape and evolution. As shown in Fig. 1, regional scale tectonic features change in orientation from the north to the south of the island $[24,45]$. A high density of strike-slip faults occurs in the Hsuehshan Range [28,41,59]. Many basins, such as the Taipei and Puli Basin, are situated within the contracting mountains [34,59-62], which also suggests that the belt was probably formed by superimposition of oblique convergence and transcurrent and rotation tectonics.

From the south to the north, a thrust wedge domain was characterized by thrust imbrications

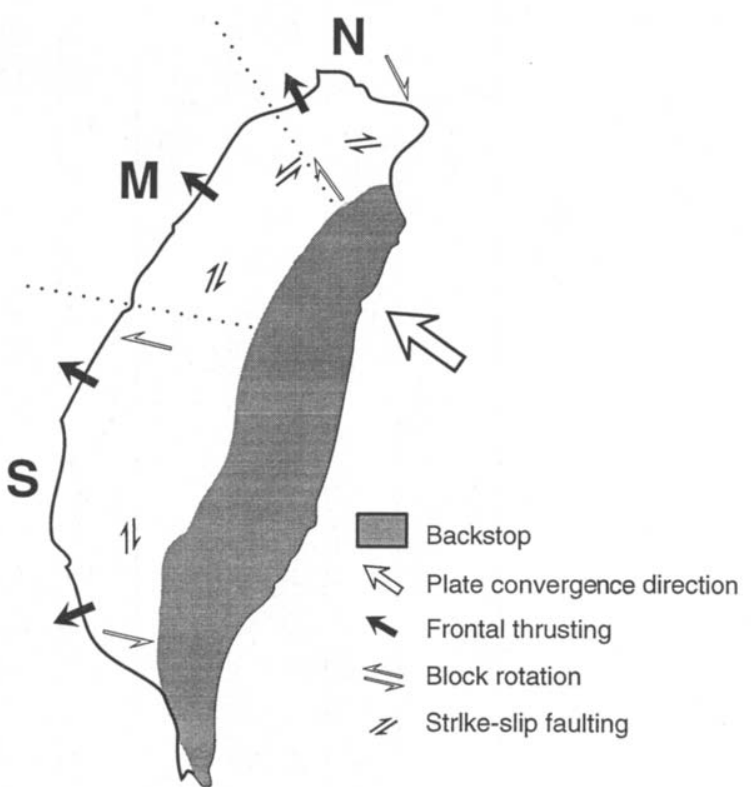

Fig. 8. The foreland thrust belt of Taiwan can be roughly divided into three domains: The northern domain $(N)$ is characterized by oblique-slip thrusts superimposed by rightlateral strike-slip and simple shear deformation; the middle domain $(\mathbf{M})$ is characterized by transpression and indentation deformation; the southern domain (S) is dominated by leftlateral oblique thrusts superimposed by right-lateral bookshelf-type strike-slip and simple shear deformation. 
and partitioning between strike-slip and oblique thrusting (Fig. 5b and Table 1-3). Thus, the most important effect of collision with an asymmetrical indenter seems to be the development of an asymmetrical thrust wedge structured into different tectonic domains.

\subsection{Post-collision tectonic evolution in the Taiwan foreland}

Analogy between field observation and experiment allows us to propose a model for the postcollision tectonic evolution of the Taiwan foreland (Fig. 8).

(1) In the southern domain (domain $\mathbf{S}$ in Fig. 8 ), most of the thrusts exhibit left-lateral oblique slip and, in places, the thrust units are cut by right-lateral strike-slip faults. The slip on these faults commonly induced transtension tectonics, resulting in the formation of rift basins or pullapart basins. The Puli Basin and a series of unnamed basins in southern Taiwan [59] may have formed by this mechanism. The kinematics of the frontal thrust in our experiment is very similar to the movement along the thrust front in southern Taiwan as determined by recent research in offshore Taiwan [63].

(2) A middle domain (domain $\mathbf{M}$ in Fig. 8) is characterized by indentation and transpression uplift. The peak of Hsuehshan, at $3885 \mathrm{~m}$ above sea level, may represent the topographic high resulting from this indentation.

(3) The northern part of the Taiwan wedge (domain $\mathbf{N}$ in Fig. 8) shows widespread rightlateral strike-slip faults. During progressive shortening, the geometry of the plate boundaries to

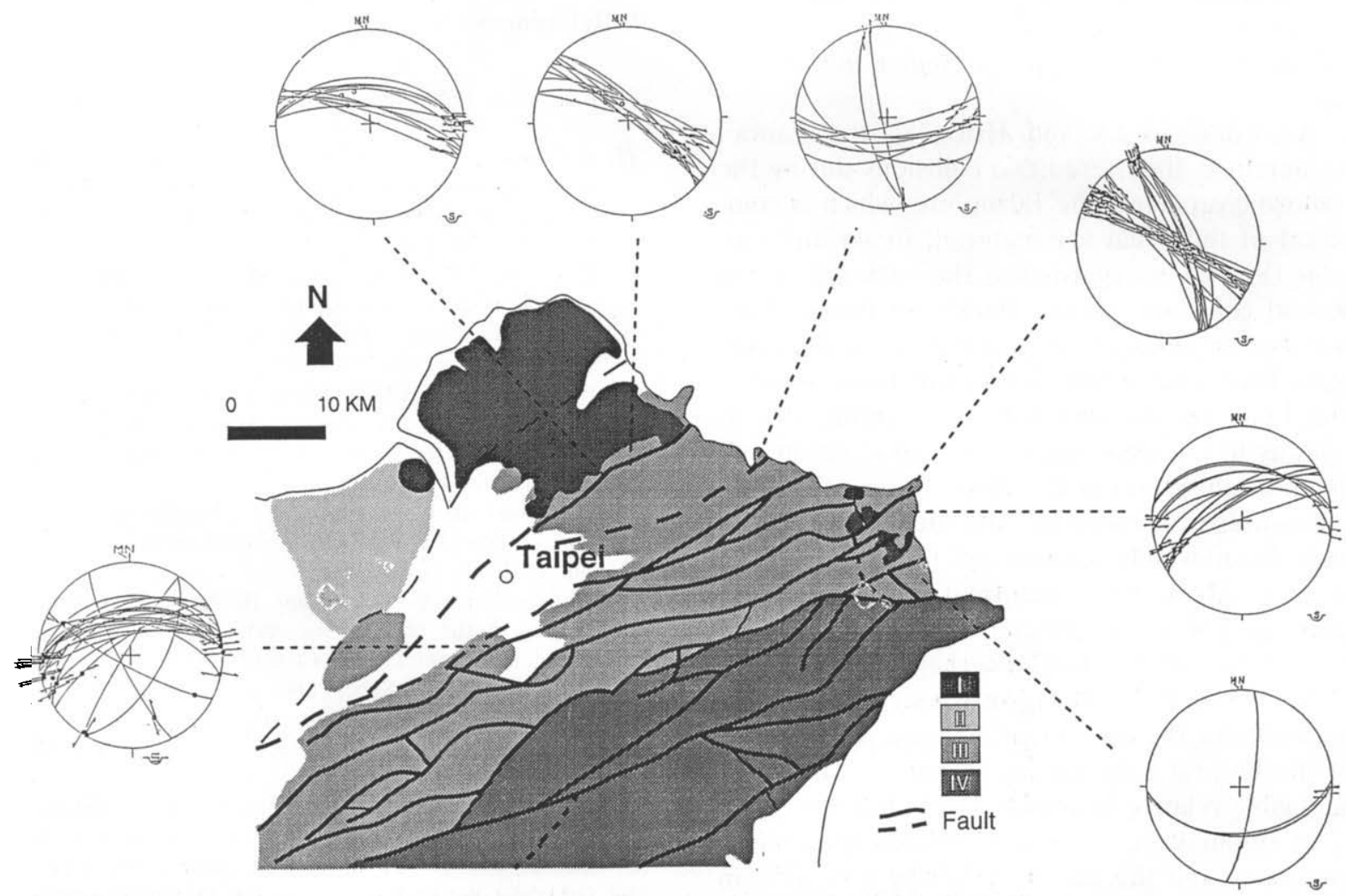

Fig. 9. Pervasive distribution of right-lateral faults in northern Taiwan. Fault-slip analyses are shown with Schmidt lower hemisphere projections of the fault planes (solid girdles). Slickenside lineations shown as small dots with small double arrows (right-lateral or left-lateral). 
the west (the Okinawa Trough) may be considered as a free border allowing right-lateral transcurrent faulting and block rotation. This is associated with left-lateral bookshelf-type strike-slip faults, which crosscut the thrust wedge. The Taipei Basin may be interpreted as a strike-slip basin related to these strike-slip faults. Figure 9 summarizes detailed studies of fault-slip data from Northern Taiwan (compiled from [64] and [65]) and shows a dominantly right-lateral strikeslip fault population in the north of the island.

Our experiment clearly shows that the amount of curvature of the thrust wedge is larger than the block rotation angles measured in Table 1 . Thus, the wedge-shaped indenter can develop the initial curved structural trend from the beginning of indentation. This important result indicates that it is more reasonable to relate part of the change in structural trend to the beginning of oblique collision [28] rather than to late block rotation.

\subsection{Deformation in the Taiwan hinterland}

According to $\mathrm{Lu}$ and Hsü [48], the Taiwan Mountain Belt suffered two collisions during the Cenozoic orogeny. The Luzon arc, which is composed of the usual arc material, flysch and molasse (Fig. 2), is regarded as the backstop of the second collision and the Backbone Range Slate Belt is composed of an accretionary wedge complex. Therefore, in the case of the Taiwan mountain building, the backstop was certainly not as rigid as in the experiment. The deformation and metamorphism in the Backbone Range, the Paleozoic-Mesozoic basement and the Coastal Range have been widely studied ([66] and references therein). Most of this deformation has to be related to the early tectonic history before the deformation of the foreland that we have modelled in this study. Thus, we have chosen a rigid backstop for the experiment because deformation of the natural backstop in Taiwan was probably negligible relative to foreland deformation.

In summary, comparison between experimental results and the geological features of Taiwan may suggest a simple explanation for the island's geometry and kinematics: progressive deformation of the thrust wedge during oblique collision.

\section{Acknowledgements}

The experiments presented in this paper were performed by the authors at the University of Montpellier II (USTL), France, when Lu Chia-Yu was visiting from September 1991 to July 1992. We wish to thank M. Mattauer, S. Calassou, A. Taboada, J.F. Ritz and B. Ildefonse of USTL Montpellier for their help and the stimulating discussion. L.C.-Y. wishes to thank P. Tapponnier and J. Angelier of Paris University, J. Ramsay and K.J. Hsü of ETH Zürich, and T. Byrne of Connecticut University for their encouragement and discussion. We also thank A.R. Perk, Biq Chingchang, D. Aerden, the two reviewers, R. Lacassin, and other, anonymous, individuals who improved the earlier version of this paper.

\section{References}

[1] P.R. Vogt, Subduction of aseismic ridges, Nature 241, 189-192, 1973.

[2] K. Burke and C. Sengör, Tectonic escape in the evolution of the continental crust, in: Reflection Seismology: The Continental Crust, M. Barazangui, ed., AGU Geodyn. Ser. 14, 41-53, 1986.

[3] P. Vialon, P. Rochette and G. Ménard, Indentation and rotation in the western Alpine arc, in: Alpine Tectonics, M.P. Coward and R.G. Park, eds., Geol. Soc. London Spec: Publ., pp. 329-338, 1989.

[4] L.E. Ricou and A.W.B. Siddans, Collision tectonics in the Western Alps, in: Collision Tectonics, M.P. Coward and A.C. Ries, eds., Geol. Soc. London Spec. Publ., pp. 229-244, 1986.

[5] P. Molnar and P. Tapponnier, Cenozoic tectonics of Asia: Effects of a continental collision, Science 189, 419 $426,1975$.

[6] P. Tapponnier, G. Peltzer and R. Armijo, On the mechanics of the collision between India and Asia, in Collision Tectonics, M.P. Coward and A.C. Ries, eds., Geol. Soc. London Spec. Publ., pp. 115-159, 1986.

[7] R. Lacassin, Kinematics of ductile shearing from outcrop to crustal scale in the Monte Rosa nappe, western Alps, Tectonics 6, 69-88, 1987.

[8] H.P. Laubscher, Large-scale, thin-skinned thrusting in the southern Alps: Kinematic models, Geol. Soc. Am. Bull. 96, 710-718, 1985.

[9] J. Malavieille, R. Lacassin and M. Mattauer, Signification tectonique des lineation d'allongement dans les Alpes occidentales, Bull. Soc. Geol. Fr. 27, 895-906, 1984. 
[10] M. Mattauer and B. Collot, Continental subduction, thrusting and strike-slip faulting in the Canandian Cordillera, Bull. Soc. Geol. Fr. 8 II 6, 899-909, 1986.

[11] J. Suppe, A retrodeformable cross section of northern Taiwan, Proc. Geol. Soc. China 23, 46-55, 1980.

[12] B. Colletta, J. Letouzey, R. Pinedo, J.F. Ballard and P. Balé, Computerized $\mathrm{X}$-ray tomography analysis of sandbox models: Examples of thin-skinned thrust systems, Geology 19, 1063-1067, 1991.

[13] D. Davis, J. Suppe and F.A. Dahlen, Mechanics of fold and thrust belts and accretionary wedges, J. Geophys. Res. 88, 1153-1172, 1983.

[14] J. Malavieille, Modelisation experimentale des chevauchements imbriques: application aux chaines de montagnes, Bull. Soc. Geol. Fr. 26, 129-138, 1984.

[15] G.S. Stockmal, Modelling of large scale accretionary wedge deformation, J. Geophys. Res. 88, 8271-8287, 1983.

[16] G. Mulugeta, Modelling of the geometry of the Coulomb thrust wedges, J. Struct. Geol. 10, 857-849, 1988.

[17] S. Liu and J.M. Dixon, Centrifuge modelling of thrust faulting: structural variation along strike in fold-thrust belts, Tectonophysics 188, 39-62, 1991.

[18] H. Lui, K.R. McClay and D. Powell, Physical models of thrust wedges, in: Thrust Tectonics, K.R. McClay, ed., pp. 71-80, Chapman and Hall, 1991.

[19] T.J. Fitch, Plate convergence, transcurrent faulting and internal deformation adjacent to Southeast Asia and Western Pacific, J. Geophys. Res. 77, 4432-4460, 1972.

[20] W.M. Chapple, Mechanics of the fold and thrust belts, Geol. Soc. Am. Bull. 89, 1189-1198, 1978.

[21] G. Peltzer and P. Tapponnier, Formation and evolution of strike-slip faults, rifts, and basins during the India-Asia collision: An experimental approach, J. Geophys. Res., 93, 15085-15117, 1988.

[22] M.K. Hubbert, Theory of the scale models as applied to the study of geologic structures, Geol. Soc. Am. Bull. 48, 1459-1520, 1937.

[23] M.K. Hubbert, Mechanical basis for certain familiar geologic structures, Geol. Soc. Am. Bull. 62, 335-372, 1951.

[24] L.P. Tan, Pleistocene eastward bending of the Taiwan arc, Mem. Geol. Soc. China 2, 77-84, 1977.

[25] J. Suppe, Kinematics of arc-continent collision, flipping of subduction, and back-arc spreading near Taiwan, Mem. Geol. Soc. China 6, 21-33, 1984.

[26] Y.T. Lue, T.Q. Lee, C.S. Horng and Y. Wong, Magnetic fabric in the non-metamorphosed terrain of the northwestern foothill-Hsuehshan belts of Taiwan, Proc. Geol. Soc. China 34, 131-146, 1991.

[27] T.Q. Lee, J. Angelier, H.T. Chu and F. Bergerat, Rotations in the northeastern collision belt of Taiwan: preliminary results from paleomagnetism, Tectonophysics 199, 109-120, 1991.

[28] J. Angelier, F. Bergerat, H.T. Chu and T.Q. Lee, Tectonic analysis and the evolution of a curved collision belt: the Hsuehshan Range, northern Taiwan, Tectonophysics 183, 77-96, 1990.
[29] J. Suppe, Geometry and kinematics of fault-bend folding, Am. J. Sci. 283, 684-721, 1983.

[30] F.A. Dahlen and T.D. Barr, Brittle frictional mountain building 1 . Deformation and mechanical energy budget, J. Geophys. Res. 94, 3906-3922, 1989.

[31] T.D. Barr and F.A. Dahlen, Brittle frictional mountain building 2 . Thermal structure and heat budget, J. Geophys. Res. 94, 3923-3947, 1989.

[32] P. Huchon, E. Barrier, J.C. De Bremaecker and J. Angelier, Collision and stress trajectories in Taiwan: a finite element model, Tectonophysics 125, 179-191, 1986.

[33] C.T. Lee, Methods of stress analysis and paleostress changes in northern Taiwan due to arc-continent collision, Dissert., Natl. Taiwan Univ., 1986.

[34] C. Biq, Transcurrent buckling transform faulting and transpression: Their relevance in eastern Taiwan kinematics, Pet. Geol. Taiwan 10, 1-10, 1972.

[35] C. Bowin, R.S. Lu, C.S. Lee and H. Schouten, Plate convergence and accretion in Taiwan-Luzon region, Am. Assoc. Pet. Geol. Bull. 62, 1645-1672, 1978.

[36] J. Malavieille, S. Calassou, S. Lallemand, C. Larroque and J.F. Stephan, Experimental modelling of accretionary wedges, in: EUG VI, Terra Abstr., pp. 367, 1991.

[37] T.C. Huang, Tertiary calcareous nannofossil stratigraphy and sedimentation cycles in Taiwan, Proc. 2nd ASCOPE Conf. Exhib., pp. 873-886, 1982.

[38] J. Suppe, The active Taiwan mountain belt, in: The Anatomy of Mountain Ranges, eds., pp. 277-293, Princeton University Press, 1987.

[39] S.C. Sun, The Tertiary basins of offshore Taiwan, Proc. 2nd ASEAN Counc. Pet. (ASCOPE) Conf. (Manila, 1981), pp. 125-135, 1982.

[40] Y. Wang, Continental margin rifting and Cenozoic tectonics around Taiwan, Mem. Geol. Soc. China 9, 227-240, 1987.

[41] C.Y. Lu, J.C. Lee and J.F. Lee, Extensional and compressional tectonics in central Taiwan, in: Neotectonics and Resources, J. Cosgrove and $\mathbf{M}$. Jones, eds., pp. 85-92, Belhaven, London, 1991.

[42] C.Y. Lu, The origin of the lithic blocks in the Tienhsiang Formation between Lo-Shao and Tzemuchiao, eastern Taiwan, Proc. Geol. Soc. China 29, 87-97, 1986.

[43] K.J. Hsü, Melange and the melange tectonics of Taiwan, Proc. Geol. Soc. China 31, 87-92, 1988.

[44] B.M. Jahn, F. Martineau, J. Peucat and J. Cornichet, Geochronology of the Taiwan schist complex and crustal evolution of Taiwan, Mem. Geol. Soc. China 7, 383-404, 1986.

[45] C.S. Ho, Tectonic evolution of Taiwan: Explanatory text of the tectonic map of Taiwan, Minist. Econ. Affairs, 1982.

[46] M.T. Brandon, E.A. Silver, N.A. Breen, M.J. Ellis and T.H. Shipley, Comments on the growth of accretionary wedges: discussion and reply, Geology 14, 184-186, 1986.

[47] R.L. Shreve and M. Cloos, Dynamics of sediment subduction, melange formation, and prism accretion, J. Geophys. Res. 91, 10229-10245, 1986. 
[48] C.Y. Lu and K.J. Hsü, Tectonic evolution of the Taiwan mountain belt, Pet. Geol. Taiwan 29, 15-35, 1992.

[49] B. Clark, D. Fisher and C.-Y. Lu, The Hsuehshan Range: A large scale crustal pop-up structure, in: Taiwan International Collaborative Research for Understanding the Subduction-Collision System in Taiwan, pp. 249-258, 1991 (Abstr.).

[50] T. Seno, The instantaneous rotation vector of the Philippine Sea plate relative to the Eurasian plate, Tectonophysics 42, 209-226, 1977.

[51] J. Suppe, Mechanics of mountain building in Taiwan, Mem. Geol. Soc. China 4, 67-89, 1981.

[52] J. Byerlee, Friction of rock, Pure Appl. Geophys. 116, 615-626, 1978.

[53] W.T. Horsfield, An experimental approach to basement controlled faulting, Geol. Mijnbouw 56, 363-370, 1977.

[54] R.W. Krantz, Measurements of friction coefficients and cohesion for faulting and fault reactivation in laboratory models, using sand and sand mixtures, Tectonophysics 188, 203-207, 1991.

[55] P. Tapponnier and P. Molnar, Slip line field theory and large scale continental tectonics, Nature 264, 319-324, 1976.

[56] P. Tapponnier, R. Armijo, I. Manighetti and V. Courtillot, Bookshelf faulting and horizontal block rotations between overlapping rifts in southern Afar, Geophys. Res. Lett. 17, 1-4, 1990.

[57] T.P. Harding, Seismic characteristics and identification of negative flower structures, positive flower structures and positive structure inversion, Am. Assoc. Pet. Geol. Bull. 69, 582-600, 1985.
[58] P. Ricard and P. Cobbold, Positive flower structures and crustal wrenches: experiments and mechanical aspect, C.R. Acad. Sci. Paris 308, 553-560, 1989.

[59] B. Chingchang, The Yushan-Hsuehshan megashear zone in Taiwan, Proc. Geol. Soc. China 32, 7-20, 1989.

[60] B. Chingchang, Some aspects of post-orogenic block tectonics in Taiwan: recent crustal movements, R. Soc. N.Z Bull. 9, 19-24, 1971.

[61] B. Chingchang, Taiwan, in: Mesozoic and Cenozoic Orogenic Belts, A.M. Spencer, ed., pp. 501-511, Geol. Soc. London, 1974.

[62] B. Chingchang, C.T. Shyu, J.C. Chen and S. Boggs, Taiwan: geology, geophysics and marine sediments, in: The Ocean Basins and Margins, F.M. Nairn, F.G. Stehli et al., eds., pp. 530-550, Plenum, New York, 1985.

[63] D.L. Reed, N. Lungberg, C.H. Liu and B.Y. Kuo, Structural relations along the margins of the offshore Taiwan accretionary wedge: implications for accretion and crustal kinematics, Acta Geol. Taiwanica 30, 105-122, 1993.

[64] H.T. Chu, Neotectonique cassante et collision PlioQuaternaire a Taiwan, Dissert., Univ. Pierre et Marie Curie, 1990.

[65] J.C. Lee, Neotectonics of Northern Taiwan, based on the faults and paleostress analyses, Thesis, Natl. Taiwan Univ., 1989.

[66] C.S. Ho, An Introduction to the Geology of Taiwan: Explanatory Text of the Geologic Map of Taiwan, 2nd. Ed., 192 pp., Minist. Econ. Affairs, 1988. 